Zagazig J. Agric. Res., Vol. 43 No. (6B) 2016

http:/www.journals.zu.edu.eg/journalDisplay.aspx? Journalld=1\&queryType=Master

\title{
MANUFACTURE AND EVALUATION OF A BAKERY-RESIDUES MILLING MACHINE FOR SNACKS PRODUCTION
}

\author{
Amira M.N. Ibrahim ${ }^{1 *}$, M.K. Abd El-Wahab ${ }^{2}$, M.A. Tawfik², Y.S. Awadallah ${ }^{2}$ and \\ M.M. El-Kholy ${ }^{1}$
}

1. Agric. Eng. Res. Inst., Dokky, Egypt

2. Agric. Eng. Dept., Fac. Agric., Zagazig Univ., Egypt

\begin{abstract}
The practical experiments were carried out to manufacture and evaluate the performance of locally manufactured bakery milling machine to reuse the bakeries residues for snacks production. The machine performance was evaluated under three different milling drum speeds of 2000, 2500, and $3000 \mathrm{rpm}$, corresponding to peripheral speeds of $10.47,13.90$ and $15.70 \mathrm{~m} / \mathrm{sec}$., respectively, three different concave clearances of $0.5,1.0$ and $1.5 \mathrm{~mm}$, three different concave-hole diameters of 0.5, 1.0 and $1.5 \mathrm{~mm}$ and the number of swinging hammers 12, 15 and 18 for evaluating the machine performance taking into account the machine capacity and efficiency, specific energy consumption and operating cost. The obtained results revealed that, it is recommended to operate the milling machine at drum speed of $2500 \mathrm{rpm}(13.90 \mathrm{~m} / \mathrm{sec}$.), concave clearance of $1.0 \mathrm{~mm}$, concave-hole diameter of $1.0 \mathrm{~mm}$ and number of hammer of 18 to achieve the highest machine capacity of 13.6 $\mathrm{kg} / \mathrm{hr}$., machine efficiency of $96.6 \%$ with the lowest specific energy consumption of $94.11 \mathrm{~kW} . \mathrm{hr} . \mathrm{Mg}$ and the minimum operational cost of $1022.1 \mathrm{LE} / \mathrm{Mg}$.
\end{abstract}

Key words: Bread-residues, performance, evaluation, hammer mill and snacks.

\section{INTRODUCTION}

Bread residues are generated in industrial factories or bakeries and removed due to the poor quality of wheat, deficiencies in baking technology, storage, distribution systems or by new market demands (commercial bread without crust). In Egypt, about $30 \%$ of all produced bread (660 from $2200 \mathrm{Mg} /$ year) end up as leftovers. Zanoni and Peri (1993) reported that, bread residues can be used as animal's feed or breadcrumbs production. Bread is a leavened product obtained from fermentation of wheat flour, sugars liberated from starch by the action of natural flour enzymes. Bread contains from 60 to $70 \%$ of flour, (14.5\% moisture, $13 \%$ proteins and $0.5 \%$ ashes. Mondal and Datta (2008) mentioned that, bread residues consists of $100 \%$ flour, rest of the ingredients will be in following measurements like leavening agent

\footnotetext{
Corresponding author: Tel. : +201002204771

E-mail address: amira_nabih2020@yahoo.com
}

yeast $2 \%$, sugar $4 \%$, salt $2 \%$ where the starch is an key component in bread dry weight. Ebrahimi et al. (2008) indicated that, flour starch is one of the main homo-polysaccharides used for energy storage and it can be found in seeds, roots, tubers, stems, leaves, fruits or pollen. The starch has remarkable physical and chemical characteristics and great nutritional quality. El Shal et al. (2010) studied the effect of some operational factors affecting the hammer mill during corn grinding and mentioned that, the hammer mill is used in preparation of grinding because of its simplicity and ease to operate. They concluded that, it is recommended to use the hammer mill at drum rotational speed of $2250 \mathrm{rpm}(33.56 \mathrm{~m} / \mathrm{sec}$.), grain moisture content of $10 \%$, concave clearance of $5 \mathrm{~mm}$ and hammer thickness of $1.5 \mathrm{~mm}$ to increase the finned milled corn and decrease the consumed energy. Egela et al. (2003) found that, the feed 
gate opening and rotor shaft speed are the most significant factors effect on the power requirement during corn grinding. The rotor speed value of $28.6 \mathrm{~m} / \mathrm{sec}$, gave more stability in the power during the grinding operation (about $2 \mathrm{~kW}$ ), which gave a safe operation for the electrical motor and less in power consumption.

Mani et al. (2004) found that, the specific energy consumption for grinding wheat straw with the hammer mill screen sizes of 0.8, 1.6 and $3.2 \mathrm{~mm}$ were 51.6, 37.0 and 11.4 $\mathrm{kW} . \mathrm{hr} . \mathrm{Mg}$, respectively at $8.30 \%$ (wb) of moisture content. Hegazy et al. (2001) studied the milling energy requirement, flour quality evaluation of rice grains and the quality of final rice flours during grinding process, the following parameters were examined. Increasing hammer revolving speeds from 750 to $900 \mathrm{rpm}$ and decreasing hammer clearance from 1.5 to $0.5 \mathrm{~mm}$., and the time of rice polishing from 1.0 to zero sec. causing a corresponding increase in the power requirements. Hegazy et al. (2002) indicated that, increasing hammer revolving speeds from 1000 to $2500 \mathrm{rpm}$ (16.6 to 41.5 $\mathrm{m} / \mathrm{sec}$.) cause a corresponding increase in the machine productivity. There is a big part of the produced bakeries remained without purchase in most of the modern bakery so it is necessary to use a simple and an economical method to convert the un-marketing bakeries residues to maximize the utility of these residues. The main aim of this research was a preliminary step to exploit and reuse the bakeries residues to produce a new food product represents in snack production. To achieve this aim, a prototype milling machine was locally fabricated for milling bakery residues, through evaluating its performance during milling french bread residues. Additionally, some operational parameters affecting the performance of the hammer mill and the operational cost of milling process were studied as well.

\section{MATERIALS AND METHODS}

The practical experiments were carried out during 2014 and 2015 seasons at the department of Agricultural Engineering, Faculty of Agriculture. Zagazig University, Egypt.

\section{Prototype Milling Machine}

The prototype milling machine was fabricated at a private workshop in Sharkia Governorate, Egypt. The specifications of the machine are presented in Table 1 and Figs. 1 and 2 display the components of the prototype milling machine.

\section{Materials}

\section{Bakeries residues}

These residues were the un-marketed french bread (Bread contains from $64 \%$ of flour, $14.5 \%$ moisture, $13 \%$ proteins, $0.5 \%$ ashes yeast $2 \%$, sugar $4 \%$ and salt $2 \%$ ) that were taken from bakeries. Then, the samples have been taken after $35-40 \mathrm{~min}$ at heat $100^{\circ} \mathrm{C}$ and analyzed to find its ingredients.

Table 1. The specifications of the milling machine

\begin{tabular}{ll}
\hline Milling machine & Hammers and screen \\
\hline Type : hammer mill & I - Hammers: \\
Hopper capacity: $3 \mathrm{~kg}$ & Type : swinging \\
Overall length : $550 \mathrm{~mm}$ & Material : Iron \\
Overall width $: 250 \mathrm{~mm}$ & Length $: 8,7.5,7.0 \mathrm{~cm}$ \\
Rotor diameter $: 120 \mathrm{~mm}$ & Width : $3 \mathrm{~cm}$ \\
Rotor width : $220 \mathrm{~mm}$ & Thickness : $3 \mathrm{~mm}$ \\
Hammer edge : circular & II - Screen \\
No. of hammers : varied & Perforation : varied \\
Power : Electrical Moto AC Motor $(1.5 \mathrm{~kW})$ & \\
\hline
\end{tabular}




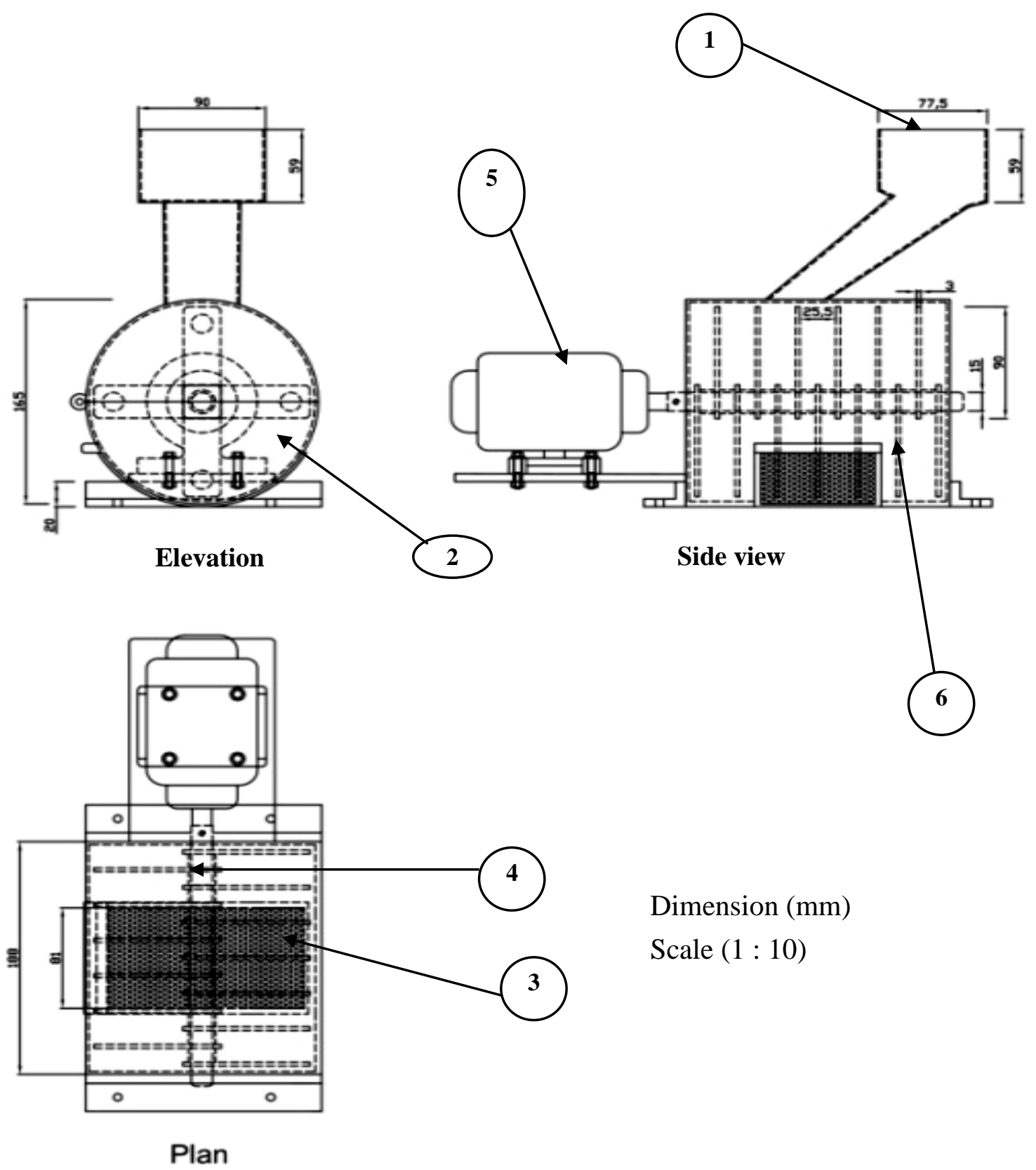

Fig. 1. Elevation, plan and side view of the prototype hammer mill.

(1) Feeding hopper, (2) Milling chamber, (3) Concave, (4) Drum shaft, (5) Electrical motor, (6) Hammers. 

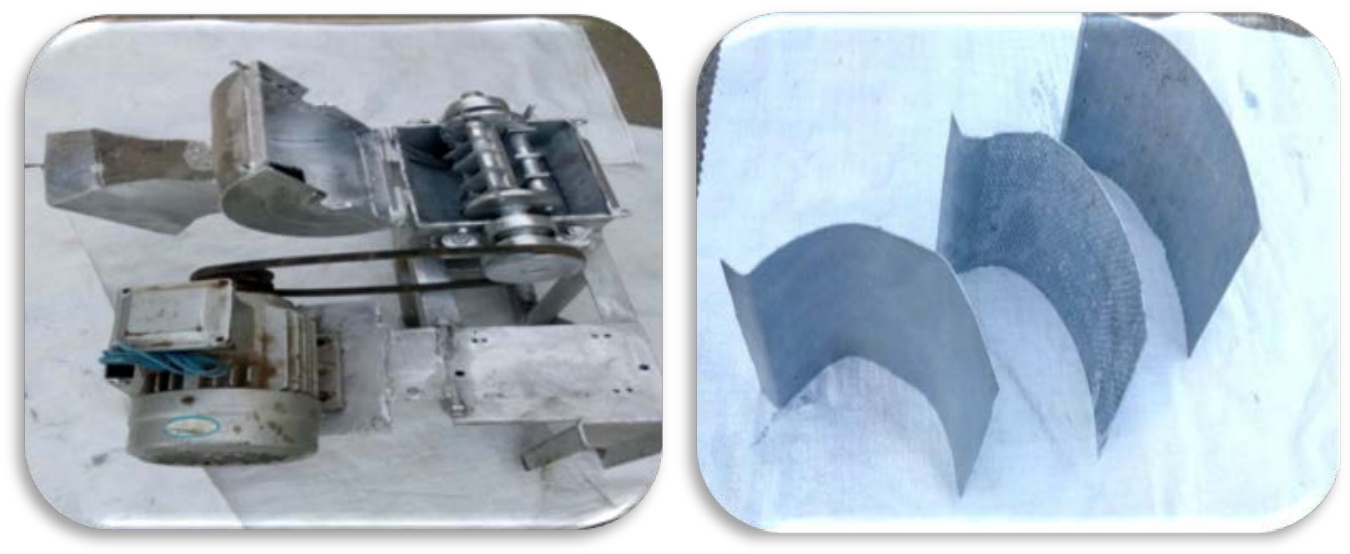

Fig. 2. The hammer mill and screens

\section{Methods}

The practical experiments were carried out to optimize some operating parameters affecting the performance of the prototype hammer mill, as follows:

1. Three drum rotational speeds of 2000,2500 and $3000 \mathrm{rpm}$ corresponding to drum peripheral speeds of 10.47, 13.9 and 15.7 $\mathrm{m} / \mathrm{sec}$, respectively.

2. Three concave clearances of $0.5,1.0$ and $1.5 \mathrm{~mm}$.

3. Three number of hammers 12, 15 and 18.

4. Three concave-hole diameters of 0.5, 1.0 and $1.5 \mathrm{~mm}$.

\section{Measurements}

The performance evaluation of the hammer mill was conducted taking into consideration the following indicators:

\section{Milling capacity and efficiency}

The theoretical milling capacity (TMC) of the machine is the rate of productivity if the machine performed $100 \%$ of the instant time. The actual milling capacity (AMC) of the machine is the actual rate of productivity by the amount of actual time consumed in operation (lost + productive time).Lost time is considered as the time spend in refilling the machine hopper, interruptions and simple repairs, El Shal et al. (2010). The milling efficiency $\left(\eta_{\mathrm{m}}\right)$ was determined using the following equation:

$$
\eta_{\mathrm{m}}=\left(\frac{\mathrm{AMC}}{\mathrm{TMC}}\right) \times 100
$$

Where:

$\eta_{\mathrm{m}}=$ the milling efficiency (\%).

TMC = the theoretical machine capacity (kg/hr.).

AMC = the actual machine capacity (kg/hr.).

\section{Power and energy requirement}

The required milling power was estimated by using the equation given by (Ibrahim, 1982)

Total consumed power $(\mathrm{kW})=\frac{\sqrt{3} I \cdot V \eta \cos \theta}{1000}$ Where:

$\mathrm{I}=$ line current strength in amperes.

$\mathrm{V}=$ potential strength (voltage) being equal to $380 \mathrm{~V}$.

$\cos \theta=$ power factor (being equal to 0.84 ).

$\eta=$ mechanical efficiency assumed (85\%).

The energy requirement was calculated by using the following equation: Energy requirement $(\mathrm{kW} . \mathrm{hr} . \mathrm{Mg})=$ The consumed power $(\mathrm{kW}) /$ Actual machine capacity (kg/hr.).

\section{Operational cost}

The cost analysis was performed and taking into account the conventional method of estimating both fixed and variable cost.

\section{Calculations of fixed costs}

\section{Deprecation cost}

Deprecation is expressed by the equation: 
Deprecation $=\frac{\text { Initial price }(\mathrm{LE})-\text { Salvage value }}{\text { Useful life }(\mathrm{hr} .)}$.

(Shepley and Schantz, 1984).

Where:

Salvage value has been assumed as 0.1 of the initial price.

\section{Interest cost}

Interest cost is expressed by the following equation:

Interest $=\frac{\text { Unit price }(\mathrm{LE})+\text { Salvage value } \times 0.18}{2 \times \text { Yearly operation }(\mathrm{hr})}$, (Shepley and Schantz, 1984).

\section{Miscellaneous cost}

Miscellaneous cost includes expenses for insurance fees, license fees, taxes and it can be estimated as follows:

Miscellaneous costs $=($ Variable costs + Fixed costs F) $\times 0.05$

When:

$0.05=$ coefficient of miscellaneous costs as a percentage of variable and fixed costs.

\section{Calculation of variable cost}

\section{Labor cost}

The cost of labor varies with location, hence the prevailing wage rate for labor was found to be 5 LE.hr. ${ }^{-1}$.

\section{Electricity cost}

The cost of electricity was determined according to the electricity consumption $=0.25$ LE.kW ${ }^{-1}$.

\section{Repair and maintenance cost}

Repair and maintenance costs are calculated based on the accumulated using the equipment and are set to be equal to the accumulated repair and maintenance divided by the lest price of the equipment. The repair and maintenance costs were determined as follows:

$$
\text { Repair and maintenance costs }=(90 \%) \text { deprecation }
$$

\section{RESULTS AND DISCUSSION}

\section{Effect of Machine Operational Parameters on Milling Process}

Fig. 3 depicts the effect of drum speed, concave clearance, concave-hole diameter and number of hammers on the milling machine capacity. As a general trend, the obtained results showed that increasing the drum speed from 2000 to $2500 \mathrm{rpm}$ (10.47 to $13.9 \mathrm{~m} / \mathrm{sec}$.), concave clearance from 0.5 to $1.0 \mathrm{~mm}$ and concave-hole diameter from 0.5 to $1.0 \mathrm{~mm}$, would increase the capacity, but any further increase in those values, the capacity tends to be stable or decreased slightly. On the other hand, increasing the number of the swinging hammers from 12 to 18 was accompanied with obvious increase in machine capacity under all treatments of the experiment. These increases in machine capacity at high drum speeds, concave clearance, concave-hole diameter and number of hammers because the high drum speed and more hammers may gave a high kinetic energy and consequently more impact on the bakery residues granular, while the increase of concave clearance and concave hole diameter causing more quantity of the ground outputted material in the unit of time and hence the machine capacity tends to increase. So, the obtained data showed that, the maximum milling capacity of $13.6 \mathrm{~kg} / \mathrm{hr}$., was achieved at drum speed of 2500 rpm (13.9 m/ sec.), concave clearance of 1.0 $\mathrm{mm}$, concave-hole diameter of $1.0 \mathrm{~mm}$ and number of hammers 18, meanwhile, the minimum milling capacity of $4.5 \mathrm{~kg} / \mathrm{hr}$., was recorded at hammer speed of $2000 \mathrm{rpm}$, concave clearance of $1.5 \mathrm{~mm}$, concave-hole diameter of $0.5 \mathrm{~mm}$ and number of hammers of 12 .

\section{Effect of Machine Operational Parameters on Milling Efficiency}

Fig. 4 shows a clear influence of drum speed, concave clearance, concave-hole diameter and number of hammers on the milling machine efficiency. It was observed that, the increase of the drum speed from 2000 to $2500 \mathrm{rpm}$ (10.47 to $13.9 \mathrm{~m} / \mathrm{sec}$.), concave clearance from 0.5 to 1.0 $\mathrm{mm}$ and concave-hole diameter from 0.5 to 1.0 $\mathrm{mm}$ would increase the efficiency but at the high values of drum speed, concave clearance, concave-hole diameter may reduce the milling efficiency. Regarding the swinging hammers, increasing the number of hammers from 12 to 18 would increase the machine efficiency slightly under all treatments of the experiment. It was noticed that, approaching of the drum speed, concave-hole diameter and concave clearance to their highest values would reduce relatively the machine efficiency. This is because the increase of the theoretical capacity is higher than to the increase occurred with the 
Concave-hole diameter $(\mathrm{mm}) \quad$ No. of hammers $=12$

$$
\begin{array}{rrrr} 
& 0.5 & 1.0 \quad 0 \quad 1.5
\end{array}
$$

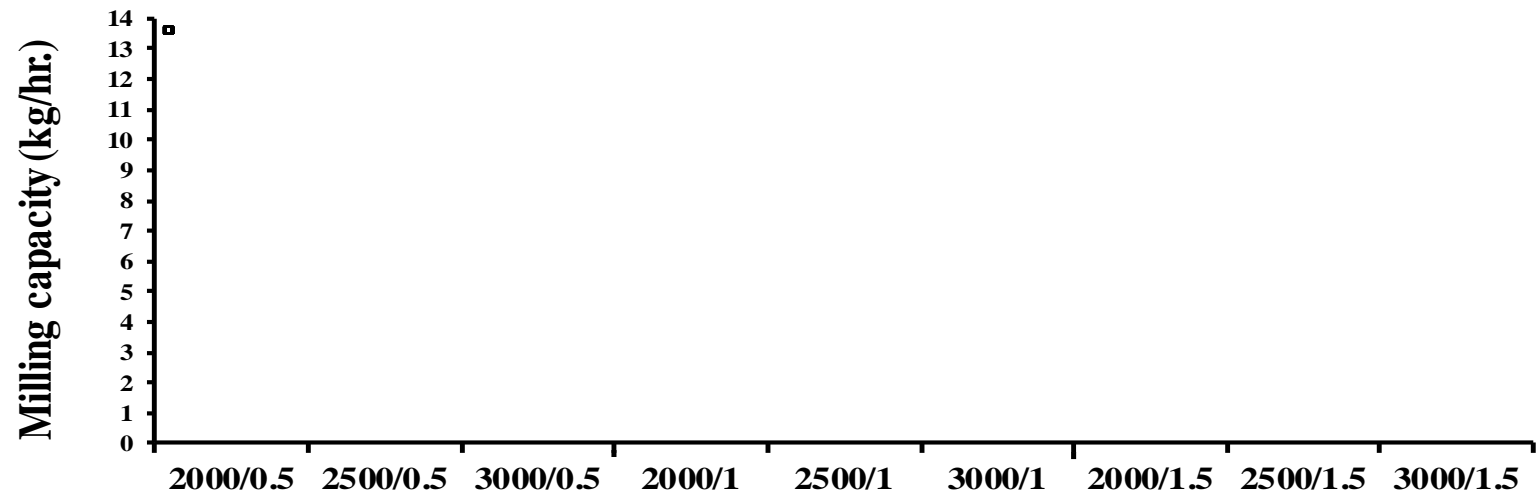

-

Concave-hole diameter (mm) No. of hammers $=15$

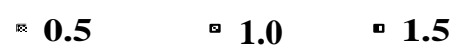

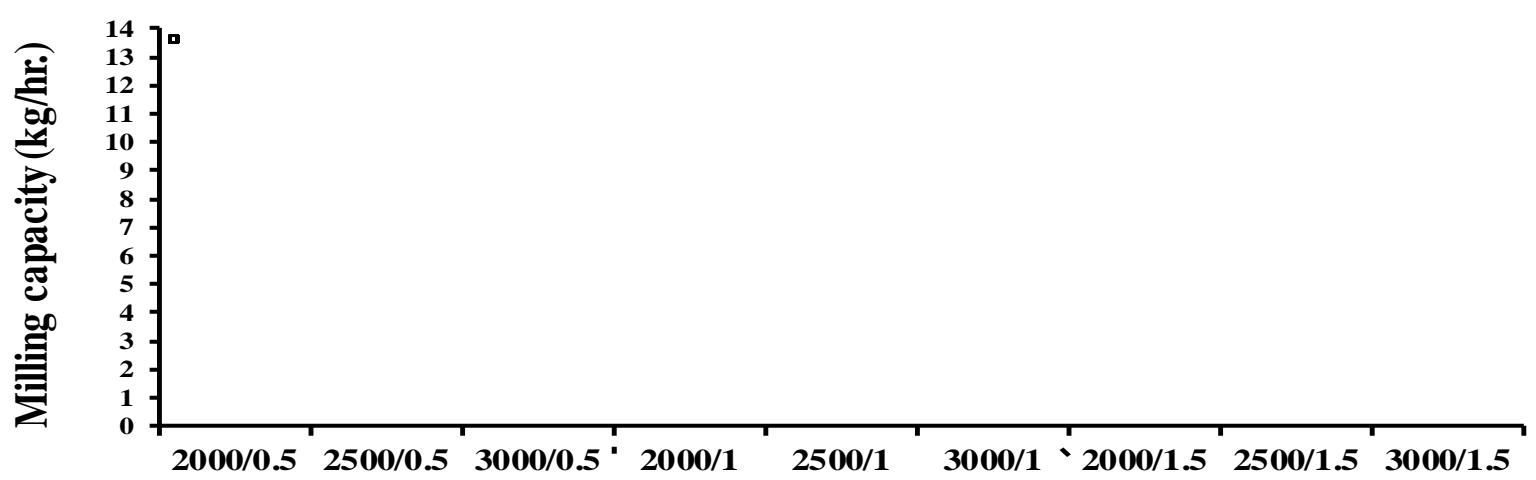

Concave-hole diameter (mm) $\quad$ No. of hammers $=18$

r $0.5 \quad 1.0 \quad$ a 1.5

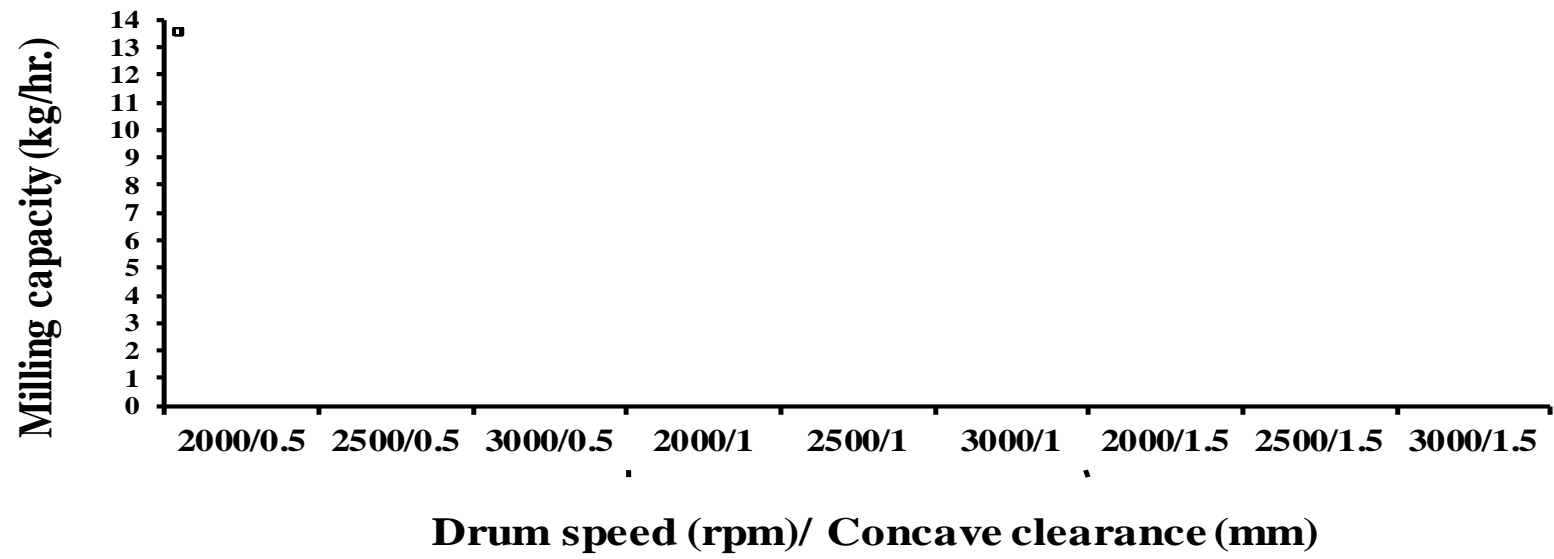

Fig. 3. Effect of some operating parameters on the capacity of the milling machine 


\section{Concave-hole diameter (mm)}

No. of hammers $=12$

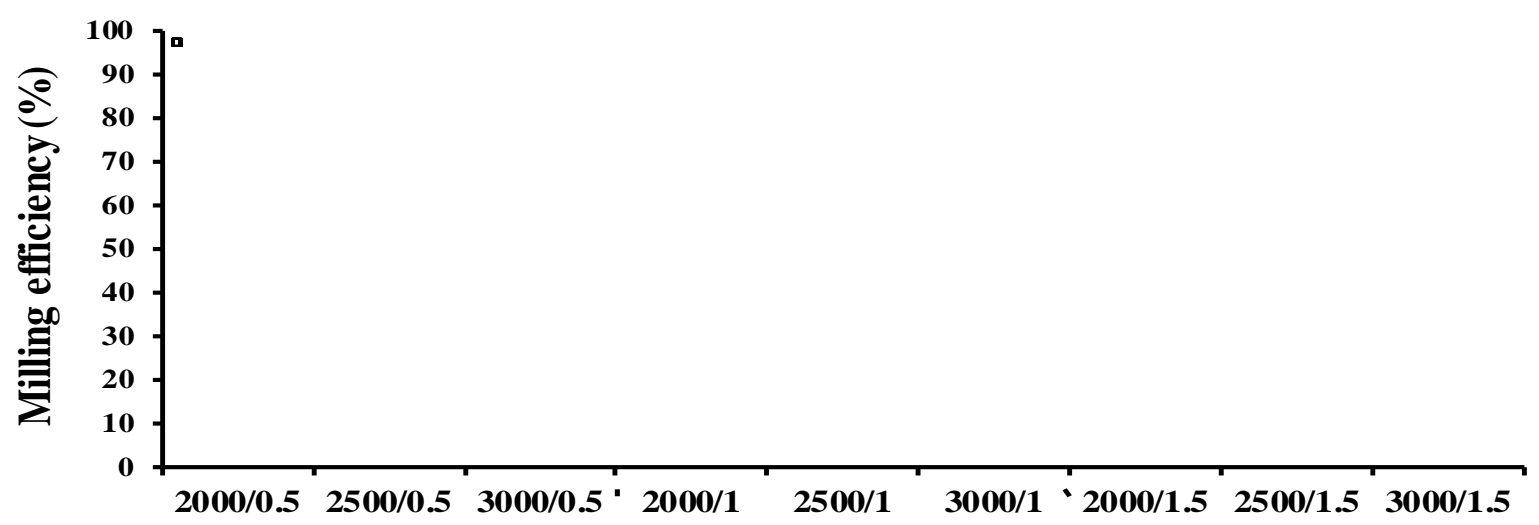

\section{Concave-hole diameter $(\mathbf{m m})$}

No. of hammers $=15$

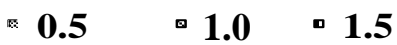

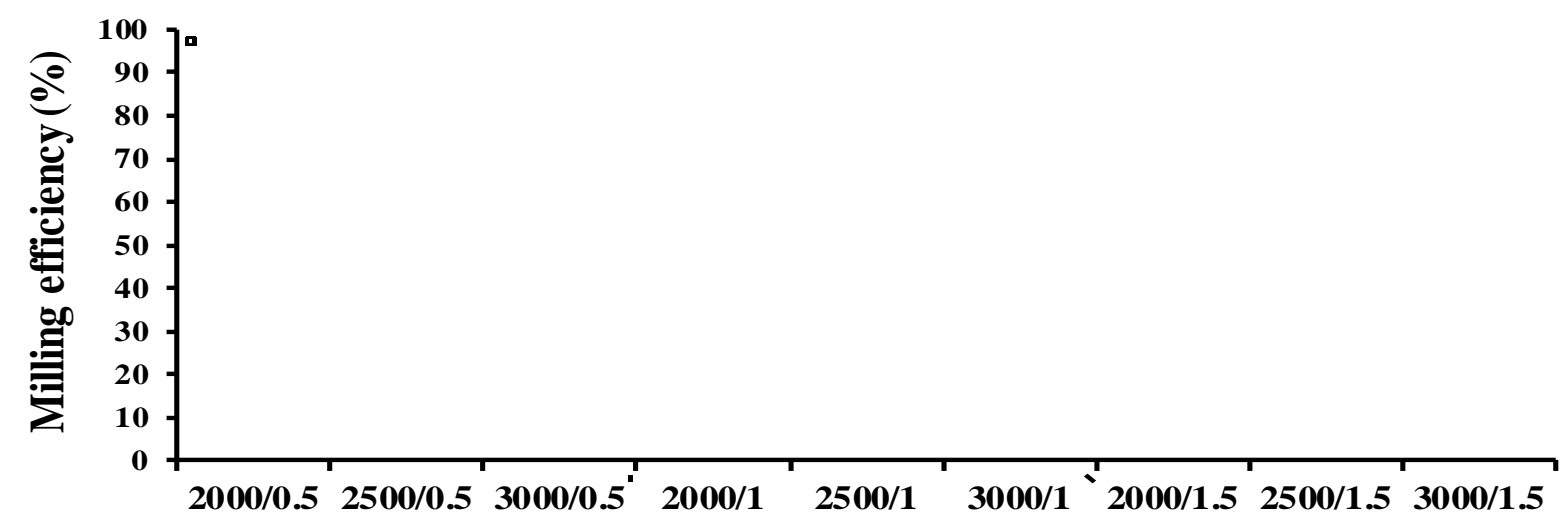

-

Concave-hole diameter $(\mathrm{mm}) \quad$ No. of hammers $=18$

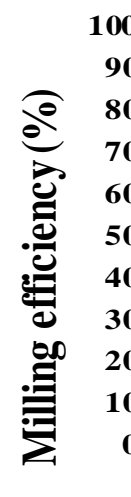

r 0.5 - $1.0 \quad$ a 1.5

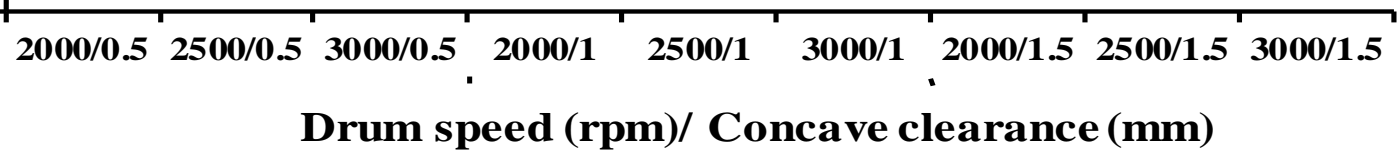

Fig. 4. Effect of some operating parameters on the efficiency of the milling machine 
actual capacity despite the rising of lost time that spent to fill the machine hopper with the bakery residues. The obtained results indicated that, the maximum milling efficiency of $96.6 \%$ was achieved at drum speed of $2500 \mathrm{rpm}$ concave clearance of $1.0 \mathrm{~mm}$, concave-hole diameter of $1.0 \mathrm{~mm}$ and number of hammers of 18. On the other side, the minimum milling efficiency of $50 \%$ was recorded at drum speed of $2000 \mathrm{rpm}$, concave clearance of $1.5 \mathrm{~mm}$., concave-hole diameter of $0.5 \mathrm{~mm}$., and number of hammers of 12 .

\section{Effect of Machine Operational Parameters on Milling Specific Energy}

Fig. 5 illustrates the effect of drum speed, concave clearance, concave-hole diameter and number of hammers on the specific energy consumption durin milling process for the bakery residues. The obtained data declared that, the consumed energy was decreased obviously by increasing the drum speed from 2000 to $2500 \mathrm{rpm}$ (10.47 to $13.90 \mathrm{~m} / \mathrm{sec}$.), but it tends to increase at drum speed of $3000 \mathrm{rpm}$ (15.70 m/ sec.).

Regarding number of hammers, it was observed that using 18 hammers and drum speed $2500 \mathrm{rpm}$ (13.90 m/sec.) for milling the bakery residues, the specific energy was decreased by increasing the concave-hole diameter from 0.5 to $1.0 \mathrm{~mm}$, then the consumed energy tends to increase again at concave-hole diameter $1.5 \mathrm{~mm}$ using concave clearance of 0.5 and $1.0 \mathrm{~mm}$. This can be attributed to the increase that occurred at the consumed power on the account of the increase of actual machine capacity at the larger concave clearance. On the other hand, the increase of concave-hole diameter from 1.0 to $1.5 \mathrm{~mm}$ was followed by a clear decrease in the consumed energy at concave clearance $1.5 \mathrm{~mm}$., the maximum specific energy of 296.1 $\mathrm{kW} . \mathrm{hr} . / \mathrm{Mg}$ was achieved at drum speed of 3000 rpm, concave clearance of $0.5 \mathrm{~mm}$, concavehole diameter of $0.5 \mathrm{~mm}$ and number of hammers of 12. Meanwhile, the lowest specific energy consumption of $94.11 \mathrm{~kW} . \mathrm{hr} . / \mathrm{Mg}$ was achieved at drum speed of $2500 \mathrm{rpm}$ (13.90 $\mathrm{m} / \mathrm{sec}$.), concave clearance of $1.0 \mathrm{~mm}$, concave-hole diameter of $1.0 \mathrm{~mm}$ and number of hammers of 18.

\section{Effect of Machine Operational Parameters on Milling Operational Cost}

Fig. 6 show the economic point of view, a complete cost analysis for the bakery residues milling process was performed for the hammer mill at different drum speeds, concave clearances, concave-hole diameters and number of hammers. It was noticed that the operational cost was reduced by increasing the concave-hole diameter from 0.5 to $1.0 \mathrm{~mm}$ then it increases slightly at concave clearance of 0.5 and $1.0 \mathrm{~mm}$ using 18 hammers and drum speed of $2500 \mathrm{rpm}$ (13.90 m/sec.). Regarding the large clearance of $1.50 \mathrm{~mm}$, the operational cost relatively decreased by increasing the concave-hole diameter from 1.0 to $1.50 \mathrm{~mm}$ due to the increase of actual machine capacity compared to the operational hourly cost of machine. Finally, the obtained data indicated that the maximum operational cost of $1055 \mathrm{LE} / \mathrm{Mg}$ was recorded at drum speed of $2000 \mathrm{rpm}$ (10.47 m/sec.), concave clearance of $1.5 \mathrm{~mm}$, concave -hole diameter of $0.5 \mathrm{~mm}$ and 12 hammers, while the minimum milling operational cost of 1021.1 $\mathrm{LE} / \mathrm{Mg}$ was achieved at drum speed of $2500 \mathrm{rpm}$ (13.9 m/sec.), concave clearance of $1.0 \mathrm{~mm}$, concave-hole diameter of $1.0 \mathrm{~mm}$ and number of hammers of 18 .

\section{Conclusion}

The results of this study revealed that, the appropriate conditions for operating the hammer milling machine to obtain the powder of the milled bread residues to be used for producing snacks were drum speed of $2500 \mathrm{rpm}$ of $13.9 \mathrm{~m} /$ sec., concave clearance of $1.0 \mathrm{~mm}$ and concavehole diameter of $1.0 \mathrm{~mm}$ using 18 hammers to achieve the highest machine capacity of 13.6 $\mathrm{kg} / \mathrm{hr}$., milling efficiency of $96.6 \%$, the lowest energy consumption of $94.11 \mathrm{~kW} . \mathrm{hr} . / \mathrm{Mg}$ and the minimum operation cost of $1022.1 \mathrm{LE} / \mathrm{Mg}$. 

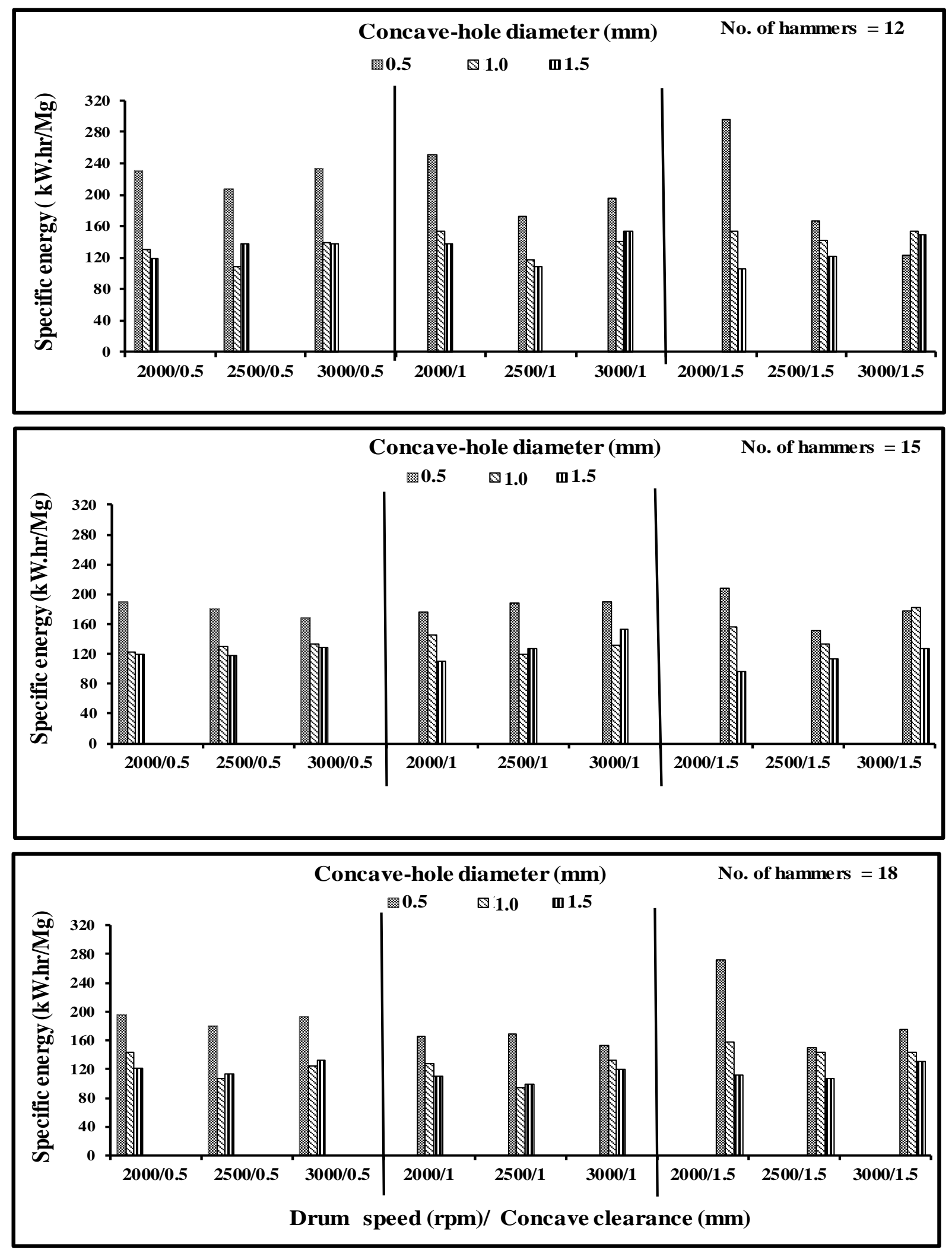

Fig. 5. Effect of some operating parameters on the specific energy of the milling machine 

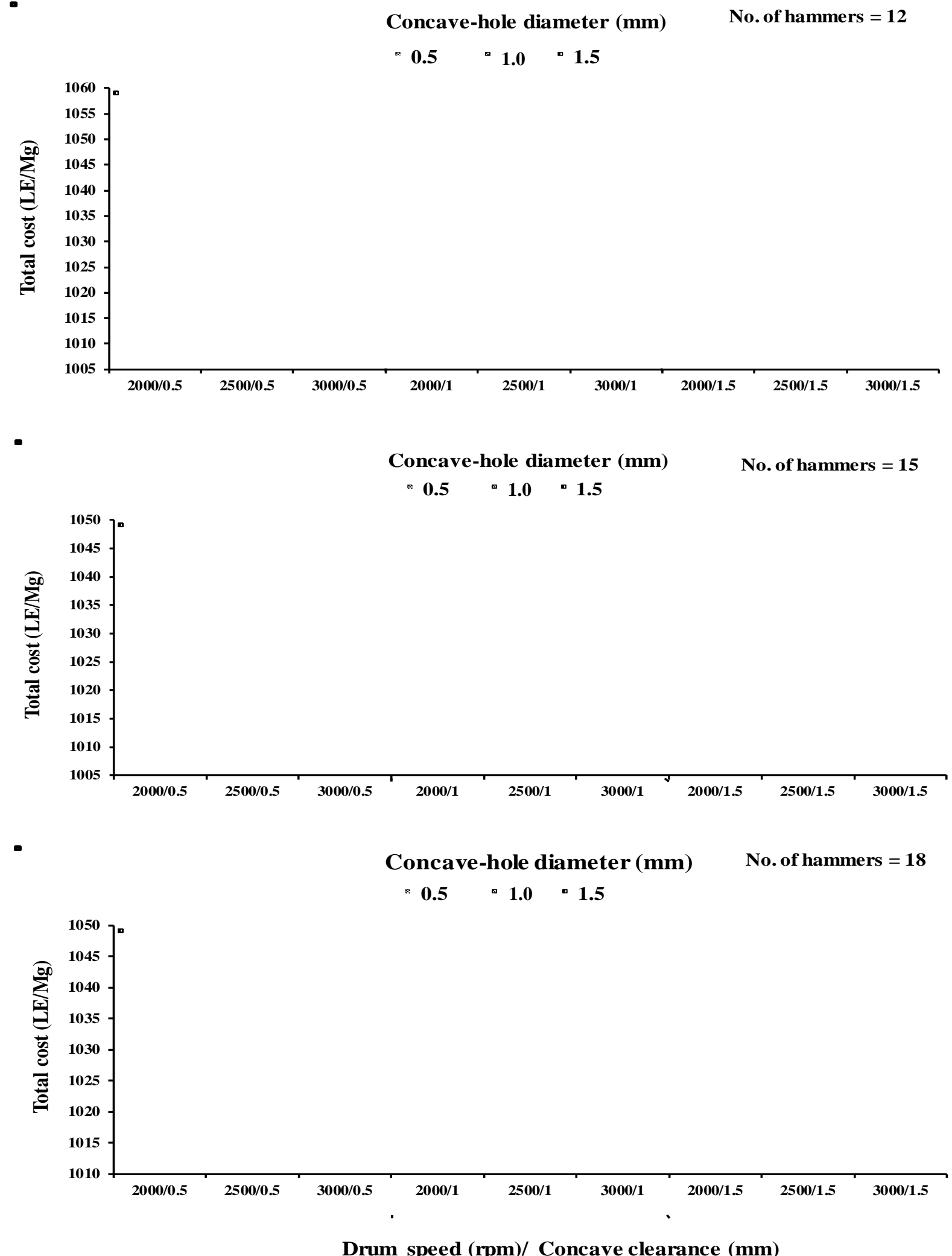

Drum speed (rpm)/ Concave clearance (mm)

Fig. 7. Effect of some operating parameters on the total cost of the milling machine 


\section{REFERENCES}

Ebrahimi, F., M. Khanahmadi, S. Roodpeyma and M.J. Taherzadeh (2008). Ethanol production from bread residues, Biomass Bioen., 333-337.

Egela, M.I., Y.F. Sharobeem and M.E. Badawy (2003). Modification of some operational parameters for local manufactured hammer mill. The $11^{\text {th }}$ Ann. Conf. Misr Soc. Agric. Eng., 15-16 Oct.: 830-840.

El Shal, M.S., M.A. Tawfik, A.M. El Shal and K. A. Metwally (2010). Study the effect of some operational factors on hammer mill, Misr J. Agric. Eng., 27 (1): 54-74 .

Hegazy, K.E.S., M.M. El-Kholy, M.M. Abd-El Rahman and M.M.A. Mosa (2002). milling energy requirements and flour quality evaluation of rice grains. Misr. J. Agric. Eng., 19 (2): 958-972.
Henderson, S.M. and R.L. Hansen (1968). Farm grain comminution. Hammer mill and Burr mill performance analyzed. Trans of the ASAE, 11 (3) : 399-402.

Ibrahim, M.K.E. (1982). Wet milling of wheat grain. M. Sc. Thesis Fac. Agric., Mansoura Univ., Egypt.

Mani, S., L.G. Tabil and S. Sokhansanj (2004). Grinding performance and physical properties of wheat and barley straws, corn stover and switchgrass. Biomass and Bioen., 27 (4): 339 - 352.

Mondal, A. and A.K. Datta (2008). Bread baking - a review, J. Food Eng., 86 465-474.

Shepley, S.C. and F. Schantz (1984). Sacioeconomic and technical evaluation of silage mower use in cotton stalk removal. Egypt Agric. Mec. Proj. Working paper, 16.

Zanoni B. and C. Peri (1993). A study of the bread-baking process. I: A phenomenological model, J. Food Eng., 19 (4): 389-398.

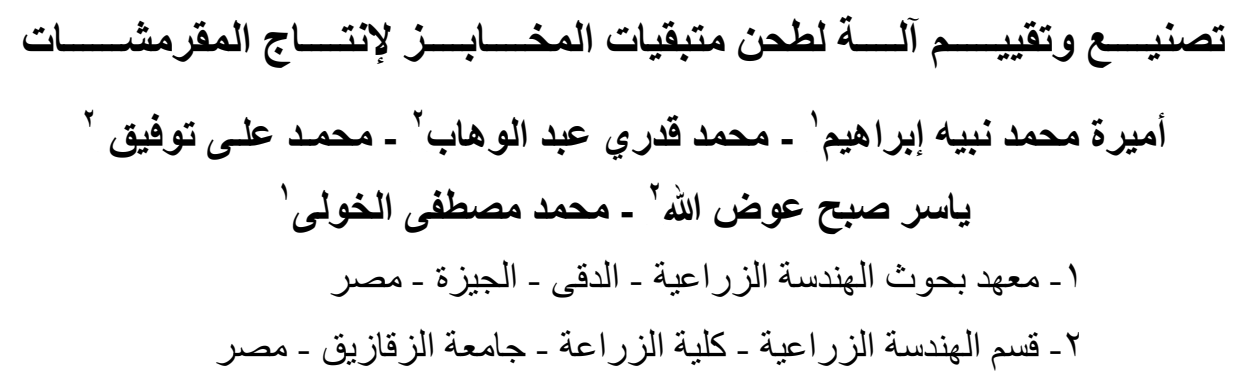

أجريت التجارب العملية لتصنييع وتقييم أداء آلة محلية الصنع لطحن متبقيات المخابز (العيش الفينو) و إعادة

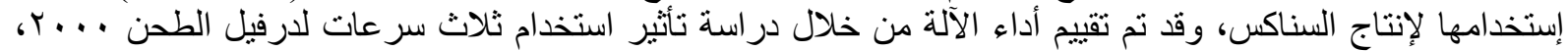

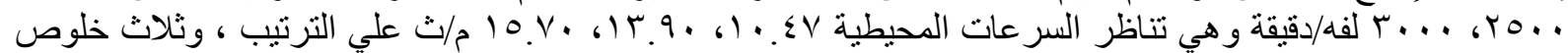

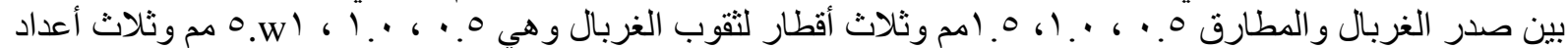

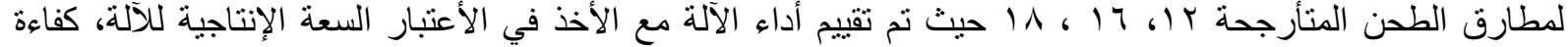

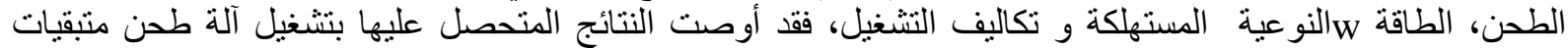

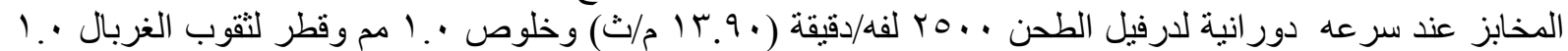

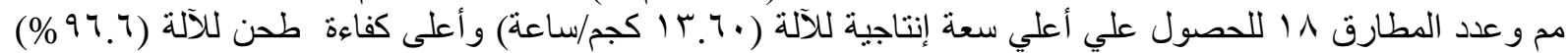

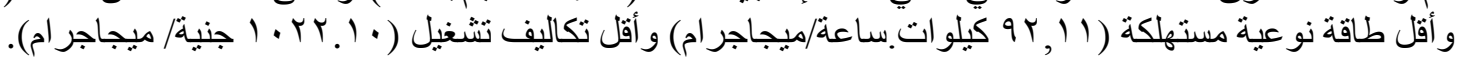

